\title{
The sociology of creativity: PART III: Applications - The socio-cultural contexts of the acceptance/rejection of innovations
}

\author{
Tom R. Burns ${ }^{\mathrm{a}, *}$, Ugo Corte ${ }^{\mathrm{b}}$ and Nora Machado ${ }^{\mathrm{c}}$ \\ ${ }^{a}$ Department of Sociology, University of Uppsala, Sweden/Lisbon University Institute/CIES-ISCTE, \\ Lisbon, Portugal \\ ${ }^{\mathrm{b}}$ Department of Sociology, University of Uppsala, Uppsala, Sweden \\ ${ }^{\mathrm{c}}$ Lisbon University Institute/CIES-ISCTE, Lisbon, Portugal/Department of Sociology, University of Gothenburg, \\ Gothenburg, Sweden
}

\begin{abstract}
The three-part article of which this one is Part III is predicated on the principle that creativity is a universal activity, essential in an evolutionary perspective to adaptation and sustainability. This work on the sociology of creativity has three purposes: (1) to develop the argument that key factors in creative activity are socially based and developed; hence, sociology can contribute significantly to understanding and explaining human creativity; (2) to present a systems approach which enables us to link in a systematic and coherent way the disparate social factors and mechanisms that are involved in creative activity and to describe and explain creativity; (3) to illustrate a sociological systems theory's (Actor-Systems-Dynamics) conceptualization of multiple interrelated institutional, cultural, and interaction factors and mechanisms - and their role in creativity and innovative developments in diverse empirical cases.

Part I of this article introduced and applied a general model of innovation and creative development stressing the sociocultural and political embeddedness of agents, either as individuals or groups, in their creative activities and innovative productions. Part II investigated the "context of innovation and discovery" considering a wide range of applications and illustrations. This 3rd segment, Part III, specifies and analyzes the "context of receptivity and institutionalization" where innovations and creative developments are socially accepted, legitimized, and institutionalized or rejected and suppressed. A number of cases and illustrations are considered. Power considerations are part and parcel of these analyses, for instance the role of the state as well as powerful private interests and social movements in facilitating and/or constraining innovations and creative developments in society.

In the perspective presented here, generally speaking, creativity can be consistently and systematically considered to a great extent as social, cultural, institutional and material as much as psychological or biological.
\end{abstract}

Keywords: Creativity, innovative development, field, agency, rule regime, creative production function, context of creativity, context of receptivity, power, the state, institutionalization

\section{Introduction}

This is Part III of a three-part article. The article is predicated on the principle that creativity is a universal activity, essential in an evolutionary perspective,

\footnotetext{
${ }^{*}$ Corresponding author: Tom R. Burns, Department of Sociology, University of Uppsala, Sweden/Lisbon University Institute/CIES-ISCTE, Lisbon, Portugal. Tel.: +46 070 8247050; E-mail: tomnora.burns@gmail.com.
}

to adaptation and sustainability. This work on the sociology of creativity has three purposes: (1) to develop the argument that key factors in creative activity are socially based and developed; hence, sociology can contribute significantly to understanding and explaining human creativity; (2) to present a systems approach which enables us to link in a systematic and coherent way the disparate social factors and mechanisms that are involved in creative 
activity and to describe and explain creativity; (3) to illustrate a particular sociological systems theory's (Actor-Systems-Dynamics) conceptualization of multiple interrelated institutional, cultural, and interaction factors and mechanisms and their role in creativity and innovative development in diverse empirical cases. ${ }^{1}$

Part I introduced and applied a general model of innovation and creative development stressing the socio-cultural and political embeddedness of agents $[9,20]$ either as individuals or groups, in their creative activities and innovative productions. Agents are viewed as socialized agents, carriers of sociocultural knowledge, including some of the knowledge essential to engage in creative processes in a particular domain or field. In their creativity, agents manipulate symbols, rules, technologies, and materials that are socially derived and developed. Their motivation for doing what they do derives in part from their social roles and positions, in part in response to situational incentives and opportunities - many socially constructed - shaping their interaction situations and domains. Their capabilities including their social powers derive from the culturally and institutional frameworks in which they are involved.

Part II investigated the "context of innovation and discovery" considering applications and illustrations in the context of organic groups, networks, organizations, and entire communities. This third segment, Part III, specifies and analyzes the "context of acceptance and institutionalization" where innovations and creative developments are socially accepted, legitimized, and institutionalized or rejected and suppressed. A number of cases and illustrations are considered. Power considerations are part and parcel of these analyses, for instance the role of the state as well as powerful private interests and social movements in facilitating and/or constraining innovations and creative developments in society. Also, consideration is given to the mixed receptivity of highly innovative contemporary developments such as GMOs and nano-materials (presented in Part II). We stress the complexity of some receptivity contexts and, indeed, the increasing complexity as more and more "stakeholders" engage in the arena(s) and try to influence developments, increasing uncertainty and risk. At the same time, many high-tech innovations (as well as large-scale undertakings) requiring major financial and technical resource inputs, are

\footnotetext{
${ }^{1}$ Burns (2006) provides an overview of several sociological systems theories.
}

made highly risky because of the complexity and the growing number of stakeholders driven to influence the creative development.

\section{Social context of reception: Agents and mechanisms of selection, legitimation, and institutionalization by key social agents and mechanisms}

\subsection{Acceptance/incorporation/ institutionalization}

As articulated in Part I, "creations" are subject to selective, and institutionalizing environments which are in large part social, economic, and political but also material and ecological. Key actors in selective environments act in response to an innovator's creations supporting them or penalizing/obstructing them to varying degrees in the field $\mathrm{F}$ and/or in the more encompassing social systems. Thus, many highly innovative creations may not be accepted and institutionalized (e.g. patented) and brought out in a market or other social field or space.

Typically, there are several phases of selection contexts, from the local or immediate selective environment, to eventually more encompassing systems including legal, economic, and political (as suggested in Fig. 2, Part I and Fig. 3B below). Responsive agents configured in networks, groups, organizations in the environment are essential to explaining the success or failure of innovative initiatives, their social acceptance or rejection, respectively. ${ }^{2}$

Creative action may be blocked through several mechanisms: because of coercive and/or persuasive opposition; ${ }^{3}$ because of a lack or denial of sufficient resources, necessary knowledge, and actor performance capabilities; or because alternative competing

\footnotetext{
${ }^{2}$ Among the key mechanisms are those that facilitate (and those agents facilitating) the spread of knowledge of an innovation. Included here is the observation - in spite of what some experts in a field say, practitioners observe that a new technology, strategy, rule complex, category system, symbol system "works," that it functions effectively, and/or that opinion-leaders in networks or media spheres advocate it. In general, experts may one judgment, and practitioners make another.

${ }^{3}$ Many inventions/creations - patented and non-patented never reach the point of commercial, military, governmental, professional (or other) applications. The blockage may occur within an organization as in the case of PARC's PC development (at Xerox) [6] or in a larger political-administrative context as in the case of Stalin's regime blocking genetic as well as relativity research/or the EU block in the realization of GMOs.
} 


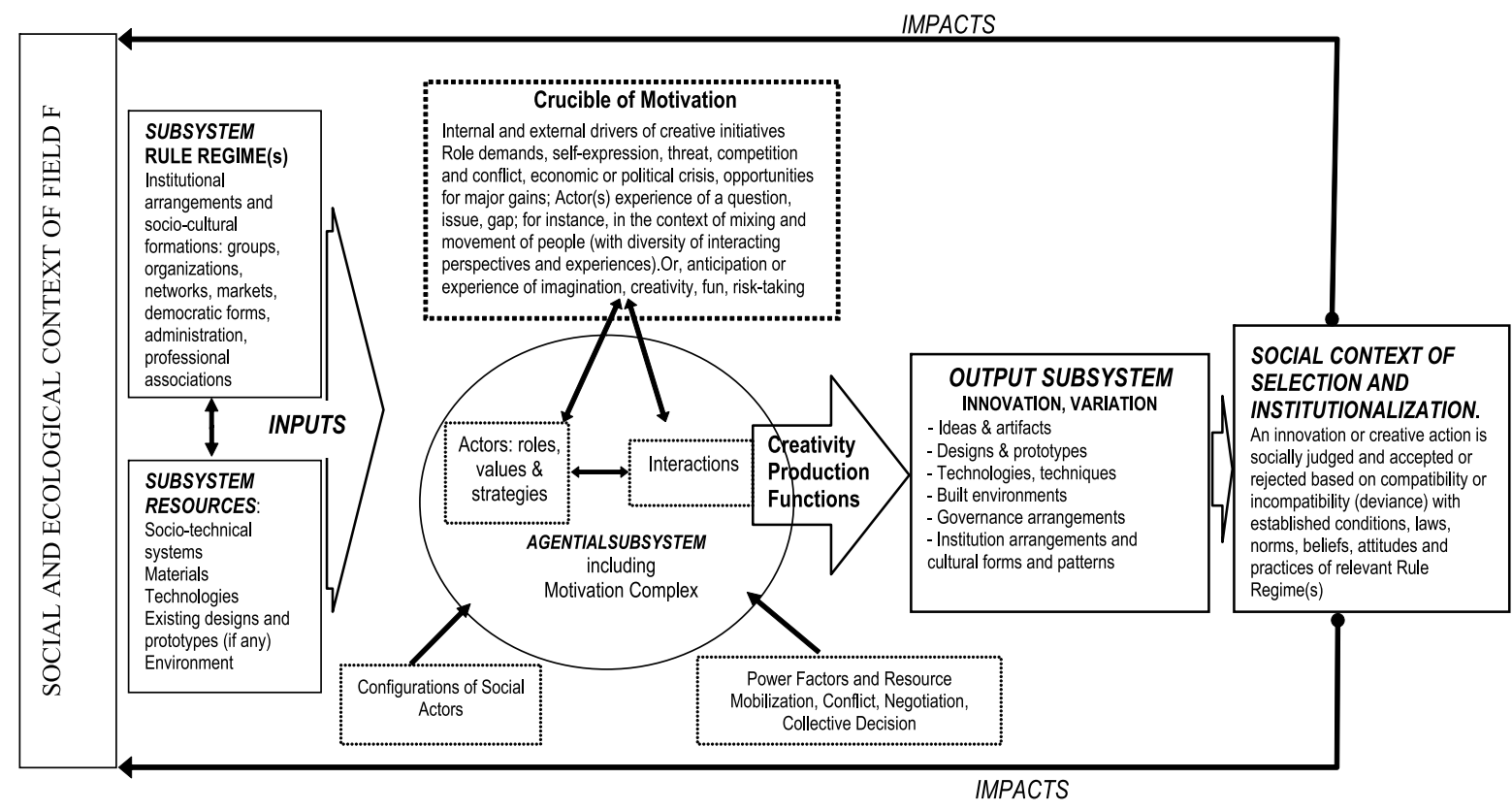

Fig. 3B. Model of Multiple Factors of Innovation and Creativity in a Social/Ecological Context.

developments may prove more attractive or more effective.

Experts (those recognized as capable of judging) in a "discipline" or field assess and encourage (or discourage) an innovation (evaluating whether "it's nonsense" or something "useful" or "promising"). In many cases, "experts" (if they are in agreement) can determine whether an innovation is approved, applied, and developed - or ignored and forgotten and unlikely to be accepted and institutionalized. For instance, key people at an organization or in a field may judge their approval and support of an innovative idea, design, technology, or system but the "market" or other institutional contexts do not approve and ignore or reject it. Agents in these larger contexts (political, economic, or cultural) may negate the innovation, although the initiating entrepreneurs, engineers, managers, and other experts more directly involved were all positively in agreement about its value or promise. Or, in the long-run, the natural environment may penalize, block or frustrate the realization and sustainability of the innovation. The context of mechanisms of judgment, acceptance (or rejection), legitimation and institutionalization is typically characterized by other processes than those associated with the innovation/discovery context (see Parts I and II). ${ }^{4}$

\footnotetext{
${ }^{4}$ Several creativity researchers conflate these contexts (see Table 2 in Part I).
}

In general, there is a politics to creativity, as in the case of most social change in terms of the mobilization of support and acceptance or opposition and suppression [13, 15]. Still, even if initially accepted and brought into social fields including markets, an innovation may fail to gain wider acceptability, or may fail sooner or later in performance, thus joining the tens of thousands of creations that don't work out (those that never come to fruition or those that have "succeeded" but over time have been confronted with sufficient mobilized opposition to make the innovation non-sustainable).

\subsection{Illustrations of selection, legitimation and institutionalization of innovative initiatives and creative developments}

In many areas of human endeavor, we have suggested that the challenge is not just to produce novelty (there are tens of thousands of novel household appliances, weapons, chemicals, medicines, production techniques, etc. that have been produced in the past 100 years and earlier (see Table 1, Part I). But there have also been major challenges to introducing and gaining their acceptance in relevant areas of application. Advanced societies see themselves as relatively "open" to innovation- arguably more so than many traditional societies; we witness many innovations being introduced, applied and developed - 
Table 1

Social agents and types of innovation and development

\begin{tabular}{|c|c|c|c|}
\hline $\begin{array}{l}\text { CHANGE AGENT } \\
\text { CONDITIONS }\end{array}$ & $\begin{array}{l}\text { ADAPTIVE OR } \\
\text { INCREMENTAL CHANGE }\end{array}$ & $\begin{array}{l}\text { RADICAL CHANGE IN } \\
\text { SINGLE FIELD }\end{array}$ & $\begin{array}{l}\text { RADICAL CHANGE IN } \\
\text { MULTIPLE FIELDS AND } \\
\text { SECTORS }\end{array}$ \\
\hline $\begin{array}{l}\text { NO COMMITTED, } \\
\text { KNOWLEDGEABLE, OR } \\
\text { CAPABLE ENTREPRENEUR } \\
\text { OR CHANGE AGENT }\end{array}$ & No Change & No Change & No Change \\
\hline $\begin{array}{l}\text { COMMITTED CHANGE } \\
\text { AGENT BUT WEAK IN } \\
\text { KNOWLEDGE, } \\
\text { AUTHORITY, RESOURCE } \\
\text { CONTROL \& } \\
\text { SOCIO-POLITICAL } \\
\text { POWER }\end{array}$ & $\begin{array}{l}\text { Low Likelihood of The } \\
\text { Desired Innovation }\end{array}$ & Innovation unlikely & Innovation unlikely \\
\hline $\begin{array}{l}\text { COMMITTED } \\
\text { KNOWLEGEABLE } \\
\text { CHANGE AGENT, } \\
\text { POWERFUL IN ONE } \\
\text { STRATEGIC FIELD (She } \\
\text { has property rights, } \\
\text { administrative authority, and } \\
\text { access to other power } \\
\text { resources, or political } \\
\text { mandate) }\end{array}$ & $\begin{array}{l}\text { Likelihood of the Innovation } \\
\text { in the Relevant Field }\end{array}$ & $\begin{array}{l}\text { Innovation likely if change } \\
\text { agent's power and knowledge } \\
\text { is based solidly in the relevant } \\
\text { field. Otherwise, innovation } \\
\text { highly uncertain, if not } \\
\text { unlikely }\end{array}$ & $\begin{array}{l}\text { Innovation very uncertain } \\
\text { (must be negotiated). } \\
\text { Necessary changes readily } \\
\text { blocked in spheres where } \\
\text { change agent weak and/or } \\
\text { opposition and structural } \\
\text { constraints are powerful }\end{array}$ \\
\hline $\begin{array}{l}\text { COMMITTED, } \\
\text { KNOWLEDGEABLE } \\
\text { CHANGE AGENT OR } \\
\text { COALITION WITH } \\
\text { ORGANIZED OR } \\
\text { ALLIANCE OF POWER } \\
\text { ACROSS THE RELEVANT } \\
\text { FIELDS }\end{array}$ & Innovation Likely & Innovation Likely & Innovation Likely \\
\hline
\end{tabular}

or opposed and rejected. Consideration of Table I (Part I) suggests the cascades of thousands of innovations that we witness around us, indicating that many have been successfully introduced and put to use. But even highly modern societies after years with some innovative technologies or other novelties try to ban or limit the use of some of them: tobacco, amphetamines, chemical and nuclear weapons. Other examples discussed below are DDT, HCFC, and GMOs. A relatively recent innovative complex is nano techniques and their thousands of "useful" applications. A large number of researchers are attempting to ascertain what are their potential negative impacts on human health and the environment. So, the future of nanomaterials - or at least some of them - is in the process of being ascertained.

There have been many creative designs and developments - from technologies to institutional arrangements - which fail to perform properly or to be accepted by key agents. Some such as the EU Baltic Fisheries Regulatory Framework failed almost from the beginning [13]. Other large-scale and initially successful innovations such as the Soviet communist system applied in the Russian Empire, and eventually to Eastern European countries, collapsed in 1989-1991 in the face of widespread critique and opposition movements. The Soviet type system managed to modernize, to provide modest levels of welfare, health, education, yet not on a level match- 
ing many Western countries. And, most importantly, the Soviet Union and its satellites fell behind technologically and militarily in several key areas as well as functioned in ways very contrary to democratic norms and the rule of law [13].

Many technological developments have been stopped, in some cases even after years of successful application. For instance, numerous food additives, a range of chemicals and medicines which at one time had been used "successfully" in applications, were later banned. For example, the refrigerant HCFCs (hydrochlorofluorocarbons) - one form synthesized in the late 1800 s was banned in the Montreal protocol 1987, because of its depletion of the ozone layer protecting life on earth from excessive ultraviolet light (ironically, widespread introduction of HCFC in refrigeration was in part the result of its low toxicity for humans compared to other refrigerants such as ammonia). DDT is another example of an initial success story which came under contention and ultimately restriction on its use. Synthesized in 1874 and its powerful insecticide action discovered in 1939, DDT was banned globally at the 2001 Stockholm convention, after a number of countries had banned it and substantial social movements opposed its use (but there were also key movements, especially in developing countries, for its continued use against mosquitoes and other serious disease vectors). The initial ban on DDT's use in agriculture emerged in response to Rachel Carson's powerful Silent Spring [14], which mapped its diverse and disastrous environmental impacts. It continues to be used modestly to control some disease vectors but this remains controversial.

There are thousands of cases of medicines which have been banned because of the discovery - sometimes long after their introduction and extensive useof their harmful effects. For example, tragically, the effective tranquilizer Thalidomide had to be stopped because it led to malformed fetuses - unfortunately this was only realized after thousands of cases had occurred. The USA's FDA never released it on the market, avoiding the catastrophe of its use among pregnant women, whereas Germany and Sweden made extensive use of it with tragic consequences.

Not all cases are resolved. The addition of fluoride to drinking water to improve the health of people's teeth has been very controversial. In Europe it is widely banned, while in the USA, it is used a great deal but banned in certain cities and regions - and controversies and struggles about its use continue, also in Europe. This is also the case with certain vaccines such as those against measles, mumps, and vaginal warts.

\section{Nuclear power}

The development of nuclear power has been blocked in several countries. Nuclear power was successfully launched and established in the case of Sweden in the period (1950-1980) and entailed a number of innovations in the type of reactor and in the hybrid state-private ownership form..$^{5}$ There had been widespread consensus in Sweden among the political parties, scientific community, and energy companies supporting the development in order to reduce dependence on oil imports. Twelve large reactors had been constructed by 1970 with plans to continue to expand the nuclear energy sector in the decades to come. However, in the early 1970s a few key elite actors, particularly in the Center Party (the old Farmer's Party) began to question the nuclear power policy in which they participated earlier. Questioning intensified significantly after "the Three Mile Island" nuclear meltdown March 28, 1979. In 1980 a referendum on nuclear power was held in Sweden to decide its future. The referendum led to a partial rejection and a decision to devolve nuclear power in 25 years (which has not happened since no acceptable alternative energy source has been found and also public opinion has shifted to be more positive toward nuclear power). Austria ${ }^{6}$ and Norway ${ }^{7}$ also launched plans to build nuclear power plants, but powerful opposition movements emerged in both countries to block further nuclear development.

\footnotetext{
${ }^{5}$ Sweden developed a light water reactor designed and built without a license from US companies.

${ }^{6}$ In 1960 it was decided to establish nuclear power in Austria. Construction began in 1972 with a German company as constructor. But by 1997, the Austrian Parliament voted unanimously in favor of remaining a non-nuclear country.

${ }^{7}$ In Norway, the Government, after deciding to launch a nuclear sector, started surveying potential sites, but a massive opposition movement emerged, and the government backed down. Parliament decided to defer decision until some time in the future [1]. In 2007, Norway took the initiative to develop a new type of fuel and reactor (based on thorium instead of uranium). The system is being tested at this time (2015) - it is being tested and developed also in China and India and several other countries. It leaves much less longlived waste such as plutonium, which is a major risk factor since it can be used to make nuclear weapons. It also appears to operate more efficiently than uranium and is suitable for alternative reactor types such as molten salt reactors that use liquid fuel and can be readily protected against meltdown. Further testing and eventual operation will determine if the costly initiative succeeds or not.
} 


\section{GMO development}

A genetically modified organism (GMO) is an organism whose genetic material has been altered using genetic engineering techniques. GMOs promised a wide range of very positive results. Organisms that have been modified include microorganisms such as bacteria, insects, plants, fish, and mammals. The technique(s) is a highly creative invention with cascading applications: the blue rose, crop foods (such as rice and corn) resistant to disease and herbicides, transgenic animals such as cows producing omega-3 milk, modification of algae to make biofuels, mosquitoes genetically manipulated to resist malaria and dengue fever, etc.

Similarly to the case of nuclear power, opposition to GMOs emerged among scientists and publics in a number of countries. This was particularly the case of several key EU countries - in contrast to the USA which by and large accepted the development of GMOs. The politics of GMO resulted in the EU putting constraints on GMO development and utilization in Europe and also constraining US exports of GMO food products to Europe. Many controversies continue about the use of the development and applications of GMO, especially concerning food available in markets. At the moment there is a relative standoff as in the case of nuclear power. ${ }^{8}$

\section{Nanotechniques and materials}

Nanotechnology is the manipulation of matter on an atomic, molecular and supramolecular scale for the purposes of research and technology development. The very conception of nano was a major innovation, resulting in multitudes of applications. There are now thousands of nanotech products publicly available with new ones appearing daily. Nanomaterials include titanium dioxide in sunscreen and cosmetics; silver particles in food packaging, clothing, disinfectants and household appliances, surface coatings, paints and outdoor furniture varnishes; further applications enable tennis balls to last longer, golf balls to fly straighter, etc. The cascading of innovations is impressive. At the same time, many researchers

\footnotetext{
${ }^{8}$ Other applications of genetic manipulation have been introduced with less controversy - although risks are recognized and discussed. Gene therapy to cure diseases is acceptable to many, especially patients with the category of disease being treated: Parkinsons, diabetes, and cancers. Thus far, such therapy is limited to non-reproductive cells; that is, transformations are not transmittable to the next generation. On the other hand, there are discussions and plans to target reproductive cells - known as "germline gene therapy - but this is very controversial and is only being tried in a few "rogue clinics."
}

and public health officials as well as publics are concerned about the as-of-yet unknown effects that the widespread manufacturing and use of nanomaterials would have on human health and the environment. One recent example: researchers have discovered that bacteriostatic silver nanoparticles used in socks to reduce foot odor are being released in washing. The particles enter into the waste stream and seem to destroy bacteria which are a critical component of natural ecosystems, farms and waste treatment processes.

In sum, an innovation and its applications always takes place within institutional, socio-cultural, and ecological/material contexts - with specific material conditions, rule regimes and symbols relevant and applied in the field or domain; and with populations and configurations of individual and collective agents who observe, judge, support, or oppose the creative activities -whether they concern new symbols, concepts, or designs, or new electric or hybrid cars, smart phones, surfboard designs, nuclear energy, GMOs, etc. (see Table 1 in Part I).

\section{Discussion and extensions}

\subsection{The societal context of creativity and innovative development}

The introduction and development of an innovation is a socio-historical process (see Fig. 3B). The process of shaping innovations entails in many cases the solution to both technical and economic problems as well as socio-political and cultural problems. The key point here is that often there are multiple, qualitatively different problems which have to be dealt with and solved in order to introduce, develop and institutionalize an innovation. Diverse actors may be recruited and involved in the complex process of trying to introduce and institutionalize an innovation in one or more contexts. In multi-agent processes, important types of actors are not only inventors and entrepreneurs, but production engineers, financial and marketing experts, adventurous consumers and opinion leaders, policy -and law-makers, as well as those involved in social and political movements, which come to influence the normative climate and relevant policy processes in the society.

These diverse actors typically play different roles, command different competencies and power resources, and are often motivated by different values and goals. The inventor(s) has the knowledge and the 
capability to formulate a new idea or to bring forth, for instance, a novel method or technology. But she often lacks the capital or the skills to bring the idea into effective production. On the other hand, someone building up production may be bad at marketing the products, at influencing the perspectives and practices of potential users, or, in general, at educating them. Educational processes are often carried out through networks of users and potential users as they communicate with one another through, for instance, their own interpersonal or professional network or through the World Wide Web. These diverse actors play out their roles at different but overlapping times in shaping new systems for producing, distributing and using an innovation. A variety of conditions and factors influence the development of such systems, facilitating, retarding and even blocking the introduction of an innovation.

- The price, quality and service advantages of innovations compared to established alternatives and their systems.

- Vested interests tend to support the conventional products, processes, and their markets.

- The supply of entrepreneurs and change agents who push for the introduction of innovations, developing new ideas, products, applications, and institutional arrangements or new fields of education and R\&D.

- Sufficiently broad and powerful coalitions of actors to pressure and to bring about required restructuring of material, social organizational, and cultural conditions in order to facilitate the introduction and development of an innovation in new markets, industries, or other settings.

- Historically, governments have played strategic roles in reducing the technical and market uncertainties and in spreading the risks involved in many innovative initiatives and developments.

Established industries or sectors have their lobbies as do relevant labor unions and communities dependent on these industries. A potentially promising innovation may have at best a few entrepreneurs looking for new markets. Workers who will ultimately get jobs in a new branch and the communities who will benefit from the implantation of new factories are not yet known (or, at least, not mobilized). They make up no lobbying force - or an embryonic one at best while the established industries and sectors with their vested interests fight changes and new developments which threaten their livelihood or positions of status and power.
This suggests the strategic importance of policies which consider branch initiatives and developments in relation to those who may be threatened or hurt by the decline of established systems and/or the appearance of new systems. Apart from this, the state, business interests, or a socio-political movement, may have an interest in the development of an innovation and may mobilize the powers essential to push through initial policy and institutional changes that will open up market opportunities (e.g., through reduction of monopolistic or oligopolistic restraints) or other institutional developments such as legal, educational, administrative, or military (the environmental movement played a key role in the early development of wind energy in Denmark [4]; see earlier discussion on the emergence of nuclear power in Sweden).

Government authorities can play a decisive role together with entrepreneurs and firms in facilitating the introduction of innovations and in getting open market developments started. Of course, as pointed out above, at times such actors may play negative roles. There is often an interplay between economics and politics. The politics centers around such issues as comparative price developments, market entry for new producers and distributors as well as $\mathrm{R} \& \mathrm{D}$ funding and subsidies, the extent of monopoly control over production and distribution, and the legal-administrative conditions under which an innovation may be introduced and used, for instance a new pharmaceutical, a new chemical, or a new energy technology (see Part II). ${ }^{9}$ The more social restructuring required because an innovation entails a radical departure from conventional entities and conditions or because powerful vested interests oppose its introduction, then the more politics is required for the introduction and development of the innovation and related systems (see discussion below). ${ }^{10}$

\footnotetext{
${ }^{9}$ Constraining or preventing monopolization of a market or, more generally a field, typically functions to encourage competition as a driver of price reduction but above all may also function as a driver of innovation [13].

${ }^{10}$ A mandate and the legitimacy to restructure facilitates and makes possible the restructuring of components in fields/domains which are not subject to market rules, such as in politics and in education, but which nevertheless affect market behavior, consumer practices, and price developments. The different institutional domains and fields of social action have their own procedures and rules of operation, their own beliefs and values. The coalition or movement backing a radical innovation must bridge these fields so as to link and coordinate the multiple changes making up a social transformation and potentially the successful emergence of an innovation and related new systems $[4,13]$. Legitimacy to restructure facilitates this task.
} 
Case studies $[4,13,36]$ demonstrate that the introduction and diffusion of innovations are subject, in general, to multiple facilitators as well as constraints. The facilitators and barriers are not only technical and economic. They are also socio-political and cultural. Vested interests in existing conditions may be all too powerful and capable of effective constraint. The power and authority of those pushing for innovations, for instance, alternative systems, may be very circumscribed, not only in terms of lobbying strength and the ability to influence policy-making, but also in terms of technical know-how and access to investment and $R \& D$ resources, or of influence on education and research policies, as well as the various policies which influence network practices of consumers.

In general, innovations - and the systems in which they become integral parts - may take a variety of paths (there is some path dependency but rarely path determinacy). Which ones will be successful -or which of several forms will be successful- cannot be determined a priori (see footnote 11). This reflects the fact that innovative developments, for instance, the introduction of new technologies into production, distribution and use, entail technical, economic, and sociopolitical problems which "must" be solved as the innovation is introduced in concrete contexts by a constellation of actors. The actors involved often give different priority to the various problems and support diverse solutions. Matters of contradictory assessment and judgement come into play. Alliances and counter-alliances may be formed. Conflicts occur in any case.

The resultant uncertainty must be managed by the entrepreneurial agents, in part simply through taking professional, political, and economic risks, in part by solving technical and economic problems and bringing about changes in government policies and regulations. Such problem-solving entails processes of adaptation, and trial and error, as well as backtracking. Most innovative development is typically not a precisely plannable activity, particularly in its early phases. As Nelson and Langlois [29:815] argue (see Fig. 2 in Part I of this article): ${ }^{11}$

\footnotetext{
11 Our case studies may be considered of two types: ex post and ex ante investigations of creative initiatives and developments. In the ex post cases, using the sociological systems framework in case reconstruction, one maps out context, the inputs, agents and their relationships and interactions, production processes, and outputs that resulted in particular innovation(s). Part of the description entails showing how the innovator(s) mobilizes and combines, adapts, and transforms the input factors, and produces original
}

“... it is an activity characterized as much by false starts, missed opportunities and lucky breaks as by brilliant insights and clever strategic decisions.

Only in hindsight does the right approach seem obvious; before the fact, it is far from clear which of

entities or constructions, using one or more creativity modalities Also, the investigation may consider failed attempts, backtracking, and loops and major sources of constraint and facilitation. Ex ante cases entail greater or lesser uncertainty about the particular inputs, the creativity production modalities, and the ultimate design and success or failure of the initiative (this uncertainty applies to the innovator(s) (as well as to the researcher unless the latter has prior knowledge of successful initiatives). The sociological systems framework enables us to identify a few key factors that, in general, are essential to most innovations and creative developments - and to investigate how they are mobilized and initially applied — or failed to be mobilized and/or properly applied. Uncertainty would be minimum if the innovative initiative entails a limited adjustment or adaptation to an established, functioning entity. On the other hand, the uncertainty is maximum if an innovator (or innovators) doesn't know, or knows only vaguely, the entity she wishes to construct or discover; one won't know relevant available materials and technologies, or what might be relevant expertise and capable and interested participants in the project. This suggests the condition of multi-dimensional uncertainty. To launch an innovative initiative, one must at least have a vague idea or a rough design, which provides an orientation to what would be essential resources, experts, other human resources, and facilitative rule regimes (for social organization, coordination, and creativity modalities) that they can or might employ in trying to produce the innovation. Between low and high uncertainty, there is a range of potential cases differing in their types and configurations of uncertainties. As Table 2 suggests, multi-dimensional likelihood analysis concerns estimating for a given field $\mathrm{F}$ and goal of innovation, the availability of resources and technologies, the available people and expertise (knowledgeable, experienced, and self-confidence persons), their social organization (the likelihood of effectiveness in mobilizing and coordinating people and resources) and the possibility and skills of conducting creativity modalities. Many of the outputs and impacts of innovative initiatives cannot be known beforehand, whether one is talking about "a new vaccine," "nano innovations," "new sources of energy," or a new type of nuclear facility because the entity and its systemic context has not fully emerged or is not clearly enough defined. The incandescent light bulb was 40 years in the making (there were dozens of patents). Although many variants were tried, most tended to burn up quickly or were too costly to produce (see Part II). Other open-ended, highly uncertain and highly costly initiatives at creativity are exemplified by various nuclear fusion developments (for instance, fusion driven by high energy lazers) (see part II on "cold fusion). Other initiatives at innovation include GlaxoSmithKline efforts, among other companies, to develop an Ebola vaccine or Merck's and other pharmaceuticals' efforts to develop an HIV vaccine (both initiatives look promising (June, 2015)) but no major breakthrough has yet been accomplished in spite of the fact that the companies have vast resources, high self-confidence, and the engagement of many scientists and institutions with years of experience). 
the bewildering array of options will prove fruitful or even feasible."

Policy and research concerning innovation and new development (including technological development) are often oriented toward "hardware," the technical aspects, as well as the economic aspects, the assessment of the likely markets and levels of demand. Social science research point up the importance of "social technologies:" organizational forms, rules and norms, policies and attitudes which affect the introduction and development of new systems. This applies to the organization of research and development, to the planning and organization of production and use of an innovation, the education of users, and the various institutional arrangements and policies which facilitate or hinder the introduction and development of innovations and new systems. We have pointed out earlier the significance of particular rule changes. Also, one should stress the importance of communication and collaborative linkages among key actor agents who play different roles in the new development.

Numerous studies suggest that innovative developments, particularly those emerging in consumer markets, are facilitated by institutions and programs which provide for:

- Constraint on monopolization (or the demonopolization) of markets related to $\mathrm{F}$ in order that competition drive innovation (as well as possibly price reduction).

- Testing and quality certification of products and the provision of warranties. For instance, in Israel, equipment guarantees for five to seven years were provided in the 1960s for solar energy systems [4]. Certification and complaint procedures have been an important ingredient in California's recent solar development. In both cases, these programs tended to reassure potential buyers who were uncertain about the quality of the products, the installation work, and the performance of the solar units.

- Equipment standardization consistent with the stage of technical development. In the case of solar development, the Standard Institute of Israel established and enforced from the mid1970s quality standards for solar equipment and its production, which facilitated the widespread adoption and use of solar energy in Israel [4]. Similarly, French government standardization of heat pumps and solar collectors through certification facilitated the market spread of these products. $\circ$ Education and training of installers and maintenance people in order to minimize equipment failure that would raise unnecessarily consumer doubts about and resistance to new products and systems. In sum, such consumer uncertainties and market failures have been a significant factor in the demand slump of many innovations including some highly innovative technologies such as GMOs.

The preceding points suggest, on the one hand, the complexity of some innovative developments and, on the other hand, the ability of entrepreneurs and other social agents to solve complex problems in the course of such developments. In part they do this by muddling through! Indeed, muddling through reflects the high uncertainty so characteristic of entirely new developments.

Clearly, an innovation is not developed and applied in the abstract, but in a particular context. It is proposed in relation to certain problems or needs, as a means to solve problems or to meet needs (including that of making a profit) or to express feelings (as in music, song, and dance). The production, distribution and use systems associated with an innovation or family of innovations develop in particular cultural, technical, economic, and socio-political contexts. These shape and regulate the innovation and problem-solving processes (possibly blocking them in some ways, and facilitating their introduction in other ways) at the same time that the developments themselves lead to restructuring of the contexts, for instance, the institutional arrangements and cultural forms that embed continuing processes.

In sum, the production, distribution and use of any innovation should be examined and analyzed in its dynamic societal and relational context. The activities associated with an innovation may to varying degrees fit into the context of established production-distribution-use systems. Typically, when an innovation is of the same general type as an established entity (or entities), its introduction entails no more than a modification or adaptation of the existing systems or of the innovation itself. The uncertainties and risks of introduction are likely to be minimal.

The introduction and development of many innovations typically entails complex problem-solving processes dealing with diverse technical, economic and socio-political problems; uncertainties and risks are high. Inventors, entrepreneurs, technicians, change agents of other types, and even social movements play important roles in creative societal 
developments and dealing with diverse uncertainties and risks. The transformation of such motive power into the launch and development of innovations and new systems can be planned and regulated only to a very limited extent. In the face of high uncertainty associated with complex technical, commercial and socio-political processes whose ultimate outcomes are not predictable, a direct and dominant government role is likely to be ineffective, even counter-productive. A government possesses no "transcendental truth" or "blue-print for the future:" it cannot "pick winners" or "weed out losers" as we discuss below (also see examples in footnote 11).

Under conditions of high uncertainty, government policy-making for facilitating innovation and creative developments in a field should be directed toward establishing the enabling conditions and incentive structures for inventors, entrepreneurs, and other change agents, including consumer groups, to take initiatives and to act creatively in introducing and developing an innovation. Governments may facilitate research and development as well as information exchange and learning generally. They may act to remove unnecessary barriers to and costs of experimentation and initiative-taking to develop alternative systems. They may encourage, through providing incentives and risk-sharing measures, entrepreneurial, technical and scientific actors to take necessary risks.

A basic problem in much contemporary market mediated innovation is that often the payoffs, returns on investments, market demand, and consumer reactions depend to some extent on government policies and socio-political conditions which entrepreneurs may be in no position to influence, for instance those that could support improvements in research and development, their production methods, improved quality control, rationalization and more effective marketing strategies. Socio-political uncertainty and turbulence increase the risks of investments and initiatives to develop innovations and, thereby, can slow down, distort, or block eventual creative development.

A climate of high socio-political or economic uncertainty makes enterprises and financial intermediaries reluctant to make expensive commitments. The longer it takes to develop, bring into production, and to market an innovation, the less likely enterprises will invest in them, especially in times of great social instability and uncertainty. Exceptions would be most likely in rapidly expanding areas or areas with opportunities for extremely large payoffs to make the risks appear worthwhile. The general tendency is for enterprises, particularly well-established enterprises to devote their R\&D budgets and investments to innovations which 'fit in' or entail only limited modifications of existing types of entities and systems. In short, this means to pursue a gradual or adaptive path of innovative change rather than revolutionary ones in order to increase the chances of acceptance and institutionalization of innovations. This is unfortunate when there is a major challenge or need for revolutionary development (as in the challenges of climate change and sustainability (see Part II)).

\subsection{Role of social power( $s$ ) in creative action and in receptivity to creativity and innovation}

Social power is a critical factor in creative applications and developments for several reasons:

(1) Social power, whether based on technical authority, command of economic resources, administrative power, or political influence, is essential to many creative formations and developments. In general introducing or establishing many of the changes - cultural, technical, economic and socio-political entailed in an innovation or creative development requires social power or the mobilization of such power.

(2) At the same time, established power structures, vested interests and infrastructures in the context of conventional conditions and practices may block many innovations and new developments, or, at least, distort or reorient them away from optimal opportunities [13, 37]. For instance, innovations are accepted or rejected, in part, on the basis of their degree of consistency with established concepts, norms and socio-political interests (in the latter case, for instance, in terms of the degree to which the innovation is perceived to reinforce, on the one hand, or to countervail or threaten, on the other hand, established positions of power and authority). Hence, public utilities tend to support large-scale energy innovation proposals, which fit into the existing systems under their control or which would be logical extensions of these systems [4]. In Sweden, for instance, electric space heating was up until the 1950s not feasible, because of the established 
power and opposition of the large-scale "electricity complex." When nuclear power was introduced, a key proponent, the Swedish State Power Board, won the support of the building industry for this development. City planners interested in district heating, plumbing engineers and related groups in opposition lost out, in part because they were not organized and could not mobilize sufficient countervailing financial, technical, and socio-political powers. ${ }^{12}$

In this way, the rapid expansion of nuclear power was combined with new electricity utilization systems (such as electric heated housing) which supported the quick growth of nuclear electricity generation and led to the stagnation of alternative systems such as municipal controlled and managed co-generation as well as district heating [24] (see earlier discussion on the rise of nuclear power in Sweden).

In general, socio-political barriers to innovation are of two general types: (1) entrenched vested interests with considerable political and economic power are able to block or undermine efforts to introduce an innovation and to establish new, or to reshape old, systems; (2) the introduction and development of new systems require restructuring in multiple domains at the same time that the entrepreneurs and

\footnotetext{
12 The struggle between co-generation and nuclear power in the 1960s was a competition and struggle between two types of sociotechnical systems: one, a cartel of electricity distributors (Swedish cities) and district heat interests and the other, the State Power Board and national utilities interested in electricity produced by hydropower and nuclear energy. The development of cogeneration required strong local authorities, able to plan heating markets through district heating but also to exercise control over electricity distribution, while the nuclear energy system required a strong central institution able to introduce nuclear reactors, adapt parts of the electricity supply system, develop new markets for electricity, and so forth. The roles of the local authority and the central utility were quite different in relation to the two technologies or technological complexes [23].

Major advances in municipal co-generation were blocked in Sweden largely because electricity supply policies, rate setting, and regulatory policies with respect to back-up power were largely under the control of the State Power Board and national utilities. The cities were faced with substantial uncertainty (determined in part politically) about future electric supply policies, back-up power and other conditions, which they lacked sufficient legal, political, or economic power to overcome. This uncertainty and the risks it implied for large investments in co-generation (together with the problems communes themselves had in financing co-generation) effectively blocked co-generation development in Sweden, although the idea was a highly innovative and costefficient one.
}

change agents pushing for the new development lack sufficient powers to bring about such extensive multidomain restructuring.

Some innovations require few changes for their introduction. They can more or less be produced, distributed and used within existing arrangements. Their deployment is likely to be more adaptive or gradual in character. As long as 'entry-barriers' or entry costs are low, an entrepreneur has clear opportunities to initiate the development process. (Of course, entry barriers or powerful vested interests against entry may raise initiative and development costs and their risks considerably).

One may distinguish between frontier fields and well-established fields. In the former there are typically fewer or no major vested interests to block or impede the introduction and development of an innovation. On the other hand, in well-organized or institutionalized fields, powerful vested interests may have to be won over or defeated in order to initiate new developments (and the infrastructures of their systems distorting or constraining many new initiatives must be transformed or replaced). ${ }^{13}$ To bring about a major innovation in such established systems, an entrepreneur or change agent needs the backing of, for example, one or more major corporations, powerful labor unions, key industry associations, utilities, and possibly the state itself, a configuration such as that mobilized in the development of nuclear energy in Sweden (and elsewhere). Or, they may require the backing of a political movement or key government agencies to bring about changes in laws, policies, and ordinances suitable for the planned or proposed innovative initiatives and developments (as in Danish wind development).

Much innovation and creative action depends on available powers, capacities, resources including positions, authorities, network contacts for action, and for carrying out creative operations. Particular material resources need to be available or mobilized for many creative actions; this is obvious, for instance, in constructing a resource-demanding builtenvironment or a large-scale socio-technical system such as nuclear or hydro-power facilities [1]. In general, an individual or collective agent has to have access to tools and resources which are used in particular creative initiatives and innovative developments.

\footnotetext{
13 As Zeleny [37:8] argues regarding established infrastructure making for significant barriers to some technological innovations "... The one-hundred years old fixation on the internal combustion engine, oil and gas, etc., can be traced to the technology support net and its constraints."
} 
Access to such powers and resources may be based on property rights, political or administrative authority or even coercive powers.

For example, in the case of alternative energy technologies, the technical, economic and political influence of the entrepreneurs and change agents engaged in developing the technologies has been, until recently, relatively weak: solar, bio-mass and small-scale wind technologies were not generally backed or driven by powerful enterprises and industries. The environmental, anti-nuclear and related social movements supporting 'soft and renewable energy sources' tended to be stronger in vision and imagination than powerful in technical, financial, production and market realms. At the same time, established energy and utility companies such as those in the petroleum and coal industries had (and still have) powerful lobbies and command considerable authority on energy matters in public forums and policymaking domains.

The more an innovation radically departs from conventional patterns and practices, or the more its introduction requires substantial restructuring of existing social systems for production, distribution and use, the more opposition it is likely to generate from vested interests in the established systems, and the greater the level of uncertainty in the acceptance and institutionalization process. Although there may be attempts to redesign and adapt the innovation to enable it to fit more easily into existing arrangements, there are often technical, economic, and socio-political or legal limits to such restructuring. Therefore, the stress may be placed on reshaping the institutional context, practices and ways of thinking associated with established systems. This sets in motion processes of support as well as opposition. The innovative development may take off or may be retarded or blocked as social groups mobilize power resources and play out various roles and strategies vis a vis the development process [5].

Radical innovations typically require the mobilization of powerful agents or a powerful socio-political movement or a coalition to bring about the necessary re-orientation and restructuring, especially in established fields where functioning alternatives are supported by powerful vested interests. This transformation does not only involve the restructuring of a variety of components linked to the effective production and use of the innovations. Nor is it simply a question of structuring sanctions and incentives to allow such innovations to grow and develop through self-reinforcing processes. ${ }^{14}$ Obtaining a mandate and legitimation to carry out restructuring is equally as important, if not in some instances more so, than receiving economic and technical support (see the cases of EU REACH regulation of chemicals and EU food regulation presented in Part II).

Consider the case of introducing radically new technologies that require shaping new and different socio-technical systems. One is not simply dealing with a slight variation or adaption of a highly compatible 'new product' but a more 'global innovative complex,' which will often require social and legal changes that cannot be carried out by technicians or entrepreneurs, but only by political agents and policymakers. $^{15}$

\footnotetext{
14 We have in mind here the possibility to generate a sufficient cash flow, to be able to attract new investors and bank loans, but also to be able to benefit from tax benefits, subsidies and other government determined benefits.

15 Wittrock and Lindstrom [35:2] who have examined the Swedish government's role in the development of hydro-power in Sweden point out (also, see [22]):" The [early] development of hydroelectric power... necessitated State involvement. The development of hydroelectric power was rendered more difficult by the prevailing legal provisions. It was necessary to introduce, among other things, legislation in government licensing in order to be able to develop the rivers and, build up the distribution systems..." The building out of the distribution net faced a great deal of opposition - "not in my backyard" with those large, zinging lines! In the case of hydro-power development, new technologies were developed, private and public capital was mobilized, and an industrial complex emerged which could overcome the obstacles of a traditional agricultural society, but this was not without substantial struggle. To introduce hydropower demanded intense legislative initiatives over a 20-year period in Sweden. Principles of right-of-way for long-distance electric transmission had to be established along with safety rules. Hydro-power installations required changes in legislation in order to force landowners into agreements about the use of "their" water rights. In effect, the expropriation of private land for the public good was established in Sweden in the development of hydro-power and long-distance electric transmission systems, as in many other developing countries. From the per-spective of societal development, this was a struggle between the proponents of two social orders (as now between the advanced industrial order and the sustainability order (see Part II)). The old water-law represented an agrarian subsistance culture while the new was better suited to an industrial order [25]. The changes in existing legislation and the enactment of new laws made the new technology development commercially viable and furthered the rapid industrialization of Sweden [35]. Nuclear power had, as would be expected, a different development logic. The initial socio-technical changes required for nuclear power development were largely on the production side - there were a number of Swedish innovations (see discussion of nuclear power in this Part and Part II). There were substantially fewer changes called for on the distribution and use side-electric grids and electricity consumption patterns were already well established. Ultimately, of course, socio-political factors, in particular public
} 
Radical innovations, for instance radically new technologies or socio-technical systems, will typically have impacts on different areas of society, not simply production systems, markets, spheres of consumption, but government policy and regulation, education, and research. For this reason the restructuring is usually carried out by - even requires for its success - an alliance of actors engaged across different social spheres and institutions in society. Such a movement carries through and integrates the technical, economic and socio-political problem-solving into more or less coherent production-distributionutilization (PDU) systems. These are not in the final analysis ad hoc collections of independent components, but systems which are largely shaped in relation to one another, that is, part of a complex network.

Inability to establish such a coalition or network across strategic spheres is likely to result in blockage of or major impediments to new developments. In general, such blockage is more likely if:

(1) A coalition supporting the introduction of the innovation fails to emerge or to hold together;

(2) The coalition of entrepreneurs and other change agents fails to formulate or develop an adequate model (theory) and strategy of realization of an effectively functioning system based on the innovation, whether a product, technology, or institution;

(3) The coalition is unwilling or unable to pay the (opportunity) costs to restructure institutional arrangements, change policies and mobilize human and material resources in order to establish an effective system based on the innovation;

(4) The coalition's social power is weak relative to actors or groups opposed to the introduction of the innovation and/or to the development of the new $\operatorname{system}(\mathrm{s})$.

In any concrete historical situation, these conditions are not fixed. Social learning, coalition formation, resource mobilization, commitments and

suspicion of nuclear power, fear of accidents, questions about security and disposal of nuclear waste and so forth has contributed to contentiousness and ultimately constraints on the full development of nuclear power (see earlier discussion about anti-nuclear opposition in Sweden and elsewhere in Europe). The early 'success' of nuclear power depended heavily on the socialization of $R \& D$ costs as well as other costs, which in many instances only slowly came to be recognized: safety and security, waste disposal, de-commissioning, and systematic regulation generally were all substantially costly. strategies undergo change. Thus, any adequate theory and strategy of the innovation-in-production-anduse will be formulated taking into consideration time. Change agents continually reassess the situation and re-commit themselves to bringing about the necessary economic, socio-political, and institutional changes. Additional resources, including expert resources, may be mobilized to effectively overcome vested interests in the established system(s) and their opposition to the innovation in question.

To sum up: the change agents who are necessary to bring about a radically new development will vary substantially from case to case, depending on the degree and type of 'incompatibility' between the innovation and established production, distribution and use systems and their particular vested interests and powers (see Table 3). ${ }^{16}$

Radical changes call for powerful collective actors or coalitions which can initiate and carry through the necessary changes in different fields and sectors, in part by mobilizing social power and strategic resources. In obvious national emergencies there may be normative pressures and social movements enabling the integration of different interests and

\footnotetext{
16 There are several degrees of incompatibility, the highest associated with the greatest likelihood of constraints and blockage: (1) Minimum incompatibility. Social, technical, economic and socio-political problems and uncertainty will be minimal. The innovation is based on ideas, analytical tools and methods fitting within the conventional paradigms and ways of thinking and doing things. That is, it can be produced, distributed and used within established systems, with at most minor modifications. This entails typically minimal challenge or threat to established power and status interests in the context F and wider contexts. (2) Limited, radical incompatibility. In this case the innovation fails to fit into at least one important sphere. For instance, although there may be few technical or scientific problems, production, distribution and ultimate use entail substantial problems, and restructuring would be necessary in one of these areas. Or there may be laws or norms which make production of the innovation problematic. If sufficient support or power can be mobilized politically to bring about the necessary legal or policy changes, the development can take off. (3) Extensive, radical incompatibility. The innovation fails to fit several domains when it is to be introduced; its introduction requires complex restructuring in multiple domains. New forms of production, distribution and use may be required. Often legal and policy changes are called for as well. The development will not take place without substantial coordinated changes in several domains and overcoming the power of vested interests and opponents. Such innovations require for their application complex, global restructuring (see earlier discussion about the introduction of hydro-power in Sweden). That is, substantial changes are required not only in immediate spheres of production, distribution and use - but in related legal and policy areas. There is a cascade of creativity associated with introducing a revolutionary innovation (see earlier discussions of GMOs and nanomaterials).
} 
the mobilization of resources across institutions and fields of social activity. This has been, in our view, a critical factor in the wartime and national emergency successes of some nation-states in radically re-orienting production and establishing new, sometimes revolutionary systems not only in the military field, but also in education, R\&D fields, and government. There are cascades of creativity under such conditions.

In sum, the costs, economic and socio-political, tend to be greater the more radical and extensive the changes entailed in trying to introduce and develop an innovation. The uncertainties and risks for entrepreneurs, investors, and possibly political leaders are correspondingly greater. The development of radical innovations requires then multiple changes, problem-solving, learning and social restructuring; shaping possibly new enterprises and organizations, new markets and market networks; establishing new public policies and laws, and the mobilization and exercise of economic as well as socio-political power. The changes which must be realized in order to introduce and develop a radical creation in production, distribution and use are realized or carried out by entrepreneurial social agents and also possibly involving their alliances. They must have access to or mobilize sufficient authority, economic resources, and political power to do this, particularly in instances where powerful social agents with vested and ideological interests oppose them. A major problem in new developments is that often the actors who have the necessary knowledge, commitments and the will to shape something new may lack the resources and social power to realize this ambition. The problem is particularly critical when changes must be carried out in several spheres of social production in order to establish effective production, distribution and use systems (see Table 1). Entrepreneurs may be able to attract finance capital and to establish production of an innovation but lack the political skills or capabilities to initiate changes in relevant government policies and regulations, which would assure the innovation's legitimacy and effective realization. Conversely, socio-political actors may bring about change in laws and government policies in order to encourage or facilitate particular innovations but fail to influence business leaders and enterprises to invest in relevant new businesses and sector developments based on a new family of innovations such as GMOs or nanomaterials; at the same time, the political agents lack the knowledge, control over resources, or legitimacy to initiate business activity themselves.
In general, one may distinguish between, on the one hand, radical and, on the other hand, adaptive/incremental innovation and system development (see Table 1) [11, 24]. Lonnroth remarks [24:33]: ${ }^{17}$

The latter can mostly be handled by the existing fields themselves, perhaps with some minor adaptation of legislation and regulation. The former frequently require much more substantial legislative changes, possibly the build-up of new institutions (or changed roles of existing institutions) and much more political action.

Lonnroth [24:33] refers to the metaphor of "the critical path," where the incremental innovation or limited gradual development has a critical path of expansion under conditions that are mainly internal to, and are handled within, a given industry or sector, while the more revolutionary innovations are subject to a critical path where the conditions necessary for successful initiation and expansion cannot be met by the sector alone but requires multiple sectors and possibly extensive government and even public involvement.

Of course, if an innovation is the 'brain-child' of large, powerful enterprises, they often have the economic and political power to mobilize and assure sufficient financing and political support across sectors. In some cases, large companies, engineering and professional groups and academic professions join forces with supporters in the government - such a configuration played a role in most instances in the development of nuclear power in many countries (the military were often also an important participating agent).

In other instances, private enterprises - particularly smaller and medium sized ones - cannot mobilize the resources and put together the political coalition necessary to shape and introduce major radical innovations - except possibly in a completely new, open field (with, for instance, open market opportunities) which lacks large or powerful institutionalized agents and, therefore, provides

\footnotetext{
17 The development of hydro-power and nuclear systems contrasts sharply with that of domestic petroleum supply systems (feeding especially into the expansion of automobile use). Market, technology, and socio-economic conditions permitted the development of oil and gasoline supply systems. The latter could be handled largely through market initiatives and development mechanisms. That is, no major political or legal action - and institutional restructuring - were necessary domestically. Only much later came the environment movement's challenges to a carbon-fuel automobile industry.
} 
opportunities for small and medium-sized enterprises to take unencumbered creative initiatives. However, for some demanding projects - regardless of the competitive context - the initiators may lack the resources, technical capability and expertise necessary to launch and establish a new development.

The more restructuring of the field (or fields) required, the greater the power resources necessary to assure that technical production, marketing, and legal-political problems can be dealt with, and uncertainty reduced or largely eliminated. The challenge may not be simply one of building think-tanks and individual production plants but establishing new social systems, training new cadres of specialists, settling issues concerning environmental and health standards, deciding land use or other resource policy questions. In sum, the uncertainties which slow down or block innovative developments may arise for diverse reasons: lack of necessary resources and technologies, technical and scientific problems, ignorance about potential users and about market demand, uncertainty about ownership and patent rights, instability or inconsistency in government policies, uncertainty about socio-political movements and political developments that could play a role in the successful introduction of the innovation and the shaping of systems based on it.

\subsection{Public power: Government involvement in innovative developments - Its uses and abuses}

As stressed above, major innovative developments entail to a greater or lesser extent the mobilization and exercise of social power(s). In many instances, such power is mobilized by business leaders, possibly political leaders, government agencies as well as other political actors including NGOs in order to support, reorient, or to possibly block new developments. Understanding innovation and new development requires a conceptualization of the ambiguous role of governments, and political agents generally [36].

The policies, strategies, and programs of governments and political agents may be important for facilitating new developments by funding $R \& D$, changing laws, regulations, codes of standards, and, in general, providing resources to and supporting new sector developments and employment opportunities.

At the same time, the power of governments or political agents generally may interfere with and disorient learning and innovation processes essential to new developments. With the best of intentions, they may try to "choose winners," deciding on a direction of development which leads prematurely to the reduction of variety (but also of uncertainty), locking the development into non-optimal or even dead-end paths [29]. In some instances, opponents to certain new developments manage to win the support of the state to block important innovations, as we have pointed out earlier in the case of powerful public utilities and energy-intensive industries in Sweden blocking alternatives-to-nuclear developments (including such innovations as district heating and municipal co-generation) [37].

What general conclusion can be reached about the limitations on and possibilities of government actors to advance or to hinder new developments? First, government agencies and policy-makers may become involved in processes of innovation and sector development as a result of their own interests as well as pressures from supporters or opponents of the innovation. Secondly, the forms of involvement, the possible roles and programs, and the dilemmas and risks of involvement may provide a frame for specifying and assessing the utility of government involvement in; new developments. Two critical dimensions here are (i) the complex phases of development (each associated with different types and degrees of uncertainty: technical, economic, legal, social, and political) (see phase model in Part I) (ii) the government's ultimate role (utilization and/or regulation) in the field(s)' eventual development. Our argument is straight-forward and can be expressed in terms of three principles.

Principle 1. The earlier the phase of development, and the greater the technical, economic, and sociopolitical uncertainties, the less the government should be involved in any direct or selective way (except concerning legal requirements and constraints on health and environmental risks). In many instances, there are available entrepreneurs and change agents willing and capable of carrying through the development process, provided they are left to themselves with sufficient resources. At most, they might require government assistance in breaking down some of the legal, administrative and policy constraints and in overcoming monopolistic and other blockages maintained by opposing vested interests in conventional systems.

In general, governments lack knowledge to make the appropriate assessments and to solve the many scientific, technical, production, and commercial problems which are involved initially in the innovation processes and in the ultimate establishment of successful production-distribution-use systems. 
Numerous studies suggest that in order to be effective, public policymaking should intervene in a substantial way only in sectors where technical or creative uncertainty has been eliminated, that is, when it is only a question of choosing between variants that are perfectly well known and their evolution foreseeable.

The state can reduce some of the risks and thereby facilitate exploration of new, promising paths of development. It can encourage processes of research and invention, facilitate contacts and communication among key groups of technicians and designers, managers, marketing experts, and users and potential users. Such a "supportive" and more indirect role is discussed more fully below.

Principle 2. The greater the degree of technical, commercial, and socio-political uncertainty in the development process, the less the state (or its agencies) should be directly or intimately involved in the process. It typically lacks the technical, economic or socio-political knowledge and judgement capability to engage in the complex assessment and sorting-out processes. In particular, it lacks in most instances the technical and economic knowledge to enable it to foresee or plan which technologies or technological developments will pay off and which will result in "flops" and "deadends." Its role in such development processes should be limited to providing resources to $\mathrm{R} \& \mathrm{D}$, facilitating information exchange and learning, and removing unnecessary barriers to or cost burdens on alternative developments (for instance, blocking a monopolization or dissolving monopoly structures to enable competition to drive innovation (that is, not just price optimization). Its policies, incentives, and subsidies should encourage scientific, technical, and commercial actors to experiment and to take calculated risks.

Principle 3. The less the government is to be ultimately involved in the use or consumption of new innovations or developments which will be introduced and developed, the more strictly the government should avoid being directly or intimately involved in the specific design of the innovation and the development of production, marketing, and educational processes associated with it. Conversely, it is appropriate and essential that the government is involved in the planning and the management of systems in which it is already playing a major role as producer and/or consumer or in which it will play such roles as in the cases of military equipment, administrative and security systems, provision of welfare services, governance and regulation, and related processes. That is, in these cases it has concrete and specific interests in, and ultimate use of, the innovation for its own activities. In some instances the government is already involved for historical reasons in a system that is in the process of transformation. In other cases, the state may become involved because it is the only actor who can provide the financing and manage the research process. In many countries, nuclear energy development has been such a case. ${ }^{18}$

A meta-management role for the state - found in cells (1), (2), and (3) in Table 2- can be distinguished from direct and intimate involvement in complex technical, commercial and socio-political decision processes whose outcomes are not predictable (see [4] and [5] in Table 2).

Below we discuss briefly three general role engagements and related strategies for government action (see Table 2). Finer distinctions can also be made as the specific technical, economic and socio-political contexts are specified.

\section{Indirect engagement: Role of meta-management of innovative processes}

Here the government's involvement is indirect and supportive, establishing laws, policies and infrastructure which will facilitate open markets and pluralist learning and development processes. Of course, policies and programs should be differentiated in terms of the phase of technological development at which they are directed (cells (1), (2), and (3) in Table 2).

\section{Direct engagement in pluralist processes: The co-determinacy role}

In cases government or government bodies are or become active in producing, distributing and/or using the innovation, they should be directly involved in the innovative learning and unfolding processes, precisely as business interests are involved in specifying the function, standards, and other demands of an eventual innovation.

But government involvement should be participatory rather than administrative, given the shared interests of business, government, and the associations and the technical, economic or socio-political uncertainties around the development. In the early stage of development, when technical, economic, or sociopolitical uncertainties are high about the

\footnotetext{
${ }^{18}$ It should be stressed that the government, through this involvement, tends to bias the technology development in the direction of large-scale systems (in relation to the resource base of the actors and the country). (See earlier discussion on hydro-power and electricity transmission development).
} 
Table 2

Matrix of government roles and strategies for innovative development

\begin{tabular}{|c|c|c|c|}
\hline \multicolumn{4}{|c|}{ DEVELOPEMENT PHASE } \\
\hline ROLE OF GOVERNMENT & INITIAL & PRODUCTION & MARKETING AND \\
\hline VIS-Á-VIS PARTICULAR & COGNITIVE-TECHNICAL & DEVELOPMENT & UTILIZATION \\
\hline SPHERES & DEVELOPMENT & & DEVELOPMENT \\
\hline \multirow{10}{*}{$\begin{array}{l}\text { LARGELY PRIVATE } \\
\text { SPHERE }\end{array}$} & Facilitate $R \& D$, for instance, & Facilitate development of & Facilitate marketing and user \\
\hline & providing incentives to & means of production. & education, learning processes. \\
\hline & business to invest in $\mathrm{R} \& \mathrm{D}$, & Formulate policies and & Regulate markets: quality \\
\hline & prototype development, & provide incentives to & control, setting standards, etc. \\
\hline & knowledge acquisition. & facilitate improvement in & {$[3]$} \\
\hline & Facilitate information & production and products, cost & \\
\hline & exchange, e.g. between & reductions, better quality, etc. & \\
\hline & potential users and & Limit monopolization and & \\
\hline & engineers/scientists. [1] & unnecessary market and & \\
\hline & & institutional constraints. [2] & \\
\hline \multirow{9}{*}{$\begin{array}{l}\text { MIXED PRIVATE/ PUBLIC } \\
\text { OR LARGELY PUBLIC }\end{array}$} & Invest in $R \& D$, either jointly & \multirow{9}{*}{$\begin{array}{l}\text { Public utilities and enterprises } \\
\text { determine production } \\
\text { standards, organize and } \\
\text { reorganize production, reduce } \\
\text { costs, improve quality, etc. } \\
\text { Government through its own } \\
\text { or joint utilization } \\
\text { implements its policies. [5] }\end{array}$} & \multirow{9}{*}{$\begin{array}{l}\text { (Not relevant unless } \\
\text { government wants to spread } \\
\text { use of the technology in the } \\
\text { public sector or sell on } \\
\text { markets). Government } \\
\text { through its own consumption } \\
\text { realizes its policies. [6] }\end{array}$} \\
\hline & with private enterprise or & & \\
\hline & separately. Engage in & & \\
\hline & dialogue with scientific and & & \\
\hline & technical networks working & & \\
\hline & on or interested in problems. & & \\
\hline & Specify function(s) and & & \\
\hline & impacts of a potential & & \\
\hline & innovation. [4] & & \\
\hline
\end{tabular}

development, government users or potential users, must be involved in defining their needs which the innovation is to satisfy. In general, the more government has special knowledge and competence in areas related to the development, for instance the knowledge of its own needs as an eventual distributor or user, the more it can be expected to be, and should be, involved actively in the development process. This role is found in cells (4) and (5) of Table 2.

\section{Direct engagement: Management role}

This role assumes that major technical, economic, and socio-political uncertainties have been resolved and that the government will be directly engaged in production and/or consumer roles. See cell (5) in Table 2 .

Any engagement of government in the production, distribution, or utilization of the innovation may reflect a historical pattern, where the state has become heavily involved in such activity, accumulating considerable experience and expertise, as, for example, in the case of publically owned utilities in many European countries (transformed since liberalization of EU electricity markets), or as indicated earlier, in military, security, and related sectors. Also government involvement may be motivated by its capacity to make large capital investments, which private interests are unable or unwilling to make. The risk here is that the government engages itself administratively in a development process where it lacks adequate knowledge and capability, or access to such resources, and mismanages the developments which it had intended to advance.

The government may have the knowledge and the resources (no small issue in times of budget cutbacks and weakened public authority) to establish and operate new systems. Nevertheless, it should not proceed - or should proceed with the greatest caution - if it has not managed to gain a public consensus or a mandate for its particular role.

A major risk in the case of public (as well as of private) monopoly over the social learning and selection processes connected with new development is that the latter will be prematurely closed. Awareness of this risk should be reflected in policy and institutional arrangements.

In general, failure to base the role of government and its strategies in new developments on considerations such as those outlined above will lead not only to wastage of resources but to distorted developments, 
blockage or slow-down of transitions to the institutionalization of an innovation and related systems.

\subsection{Creative success and failure: A systemic, multi-dimensional perspective}

Success of innovation initiatives are a function of multiple factors, a number of which have been identified in this article (see Parts I and II). At the same time, failures of initiatives may depend on one or a few factors. Many creative initiatives are initiated, and many of them fail $[4,27]$. As we have suggested with some of our illustrations, some may succeed initially, and then fail later after participants or observers accumulate experience—or the validation and power context and/or judgment frame shifts. Also, creations ignored or blocked in one context or historical period may be rediscovered or revived at a later time.

As indicated earlier, the likelihood of a creative production in a field depends on the objective or purpose of the production and the innovator's ability to mobilize and to put together the essential ingredients of people and resources in the creativity production processes. Successful innovation and development is likely to be accomplished when an agent or agents is able to formulate essential ideas or designs and carry out production functions integrating necessary input resources and people. This involves (see Part II):

Availability of knowledgeable, capable entrepreneurial agents in field $\mathrm{F}$

- Availability of essential materials and technologies to be deployed in the production processes in $\mathrm{F}$

- An agent or agents motivated and sufficiently "free" or autonomous as well as self-confident are available to carry out one or more creativity production processes - that is, to a greater or lesser extent she is free from cultural and institutional impositions (laws, policies, monopoly conditions, normative climate, and other structural forces) that constrain the framing and definition processes, the mobilization of resources, the realization of creativity production functions.

- Appropriate norms facilitate and support creativity. In the case of multi-agent processes, a normative order may facilitate and encourage communication, sharing of knowledge and expertise, and collaboration among participants increasing the likelihood of successful creative outputs.
These and related factors identified and discussed here relate to the likelihood of producing a successful innovation. But, as we have stressed in our models, generation of an innovation is necessary but not sufficient for an innovation's acceptance and utilization in social life, for instance in a market (for a general consideration of the concept of emergence, see Buckley [7]). Social mechanisms of acceptance and institutionalization are also an essential part of the ultimate success of a novelty or creation (see Figures 3B and 4).

An innovation is likely to be accepted and incorporated/institutionalized in field $\mathrm{F}$ when:

- It fulfills a need or purpose at least in the perspective of key agents in $\mathrm{F}$ (or others with the power to intervene in and influence the development of F).

- It fits easily into established cultural and institutional conditions, for instance, the normative and legal order at the same time that expected costs are low and/or payoffs are high.

- Challenges to, or limitations on, the status and power of key initiating agents is low.

- Nonetheless, in contemporary democratic societies, the acceptance process may be difficult and slow because there are multiple stakeholders with diverse values and perspectives who have considerable rights and powers to influence creative developments.

- In developed societies and more and more in developing countries, there is the ready availability of scientists and technicians to raise questions, provide arguments to policymakers and stakeholders about unintended negative consequences.

- At the same time, the citizenry of individuals may not be in a position to constrain or block a major creative initiative drivern by powerful companies and/or the state.

- Depending on the distribution of societal power, general public opinion may be either reinforcing, ambiguous or powerless in the face of an innovative initiative (as the history of many megaprojects such as nuclear power demonstrate [1]).

The life cycle of an innovation is not limited to the acceptance/non-acceptance dichotomization, at least not in an historical or evolutionary perspective. Even successful, highly institutionalized creations may be ultimately phased out or substantially constrained, as illustrated in several of our cases-for example, nuclear energy, an EU energy tax, and GMOs [15]. Opposition emerges among scientists, in the mass media and within the larger publics, and play a crit- 


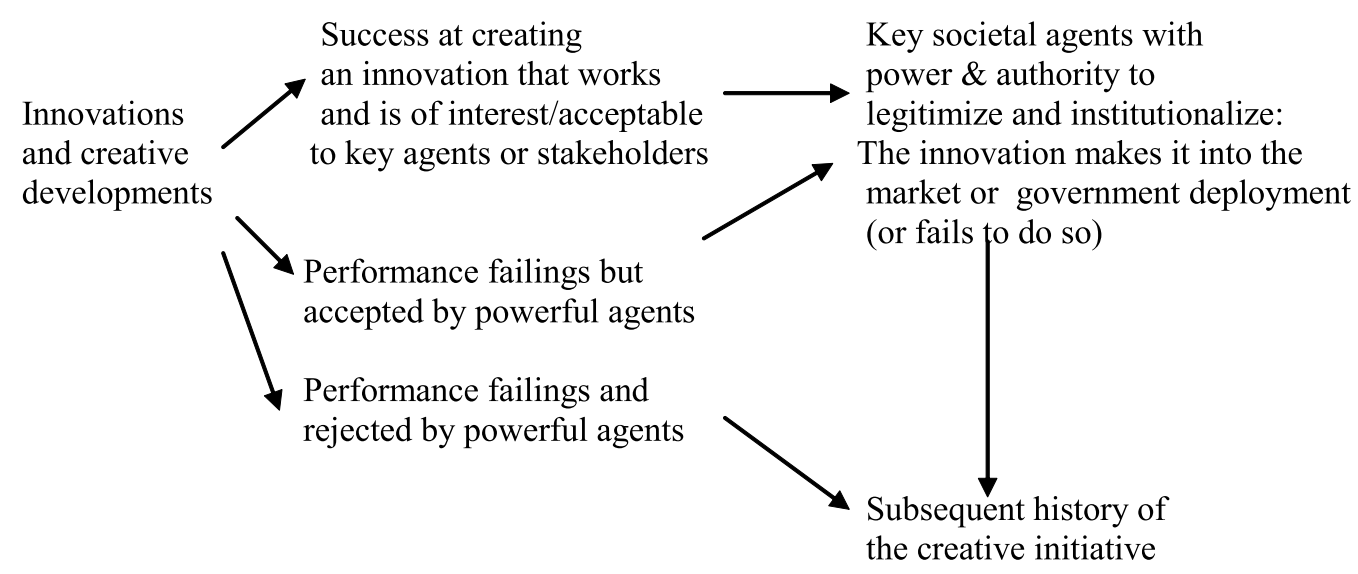

Fig. 4. Development Model.

ical role in the constraint on, or blocking of, some creative developments. For instance, nuclear energy construction has been blocked or stalled in a number of countries. Similarly, there has been more or less blockage of GMO development in the EU. On the other hand, blocked or defunct reations may be revived or re-discovered. The latter provide numerous examples:

- After their obsolescence, windmills were reintroduced in Denmark in the $1970 \mathrm{~s}$ in the context of environmental concerns and environmental social movements. This was a major part of the renewed interest and development of windmills not only in Denmark but internationally [4].

- Rediscovery in developed countries of the technique of breastfeeding has been replacing the highly innovative industrial produced powdered milk and formulas for infants.

- Rediscovery of defunct ecological methods are replacing to a limited degree the highly creative industrial methods of modern agricultural cultivation (see Part II on the sustainability revolution).

We have stressed that an agent may succeed in innovating, even radically, but that the context of acceptance and institutionalization of the innovation is in large part decisive in its ultimate success or failure. The distinction between the two contexts, that of creativity and that of social receptivity, is a matter of degree (see [16] concerning the links between the two contexts). Often the contexts are closely linked (as in many groups and companies that are producing innovation for themselves). In a highly democratic society with developed public opinion and widespread capacities to mobilize peo- ple to support or oppose a creative initiative, public receptivity is a critical variable in any consideration of innovation and creative development.

\subsection{Likelihood patterns in the context of acceptance and legitimization processes}

Table 3 provides a simple scheme of likelihood patterns of acceptance and rejection of innovation. The Table indicates, for instance, patterns of likely acceptance and institutionalization as a function of the compatibility between the innovation and the context where it is to be introduced and established, the extent to which the innovation challenges or threatens key agents of power and status, or the extent to which the initiators have superior or countervailing power.

From our earlier examples and discussions in Parts I and II, failure of a particular innovative initiative is not only then a question of non-available or scarce resources and technologies ("the need for a more funding") or the limited knowledge, capabilities, and social relations of the agents involved ("the need for greater expertise and entrepreneurship," or the "need for a more creative social interaction or climate"), but depends also on oppositional and political forces generated within institutional, network, and other relevant power contexts.

Agential factors may constrain or block innovative initiatives and developments-for instance, key actors are in a position to decide over the mobilization and allocation/deployment of crucial resources. They may do this because they are culturally/normatively narrow, or unimaginative, or because they have vested interests in existing systems and are opposed to 
Table 3

Two divergent patterns: high likelihood of success/low likelihood of success of gaining acceptance and institutionalizing innovations and creative developments and gaining acceptance. (see Principles in Part II)

\begin{tabular}{|c|c|c|c|}
\hline $\begin{array}{l}\text { LIKELIHOOD OF } \\
\text { ACCEPTANCE, } \\
\text { INSTITUTIONALIZATION }\end{array}$ & $\begin{array}{l}\text { Low Likelihood of } \\
\text { Acceptance and } \\
\text { Institutionalization }\end{array}$ & $\begin{array}{l}\text { Uncertain Likelihood of } \\
\text { Acceptance and } \\
\text { Institutionalization }\end{array}$ & $\begin{array}{l}\text { High Likelihood of } \\
\text { Acceptance and } \\
\text { Institutionalization }\end{array}$ \\
\hline $\begin{array}{l}\text { Degree innovation fits (or } \\
\text { fails to fit) into cultural and } \\
\text { institutional arrangements } \\
\text { (the established paradigms) }\end{array}$ & High degree of misfit & Medium degree of misfit & Low degree of misfit \\
\hline $\begin{array}{l}\text { Degree innovation challenges } \\
\text { the status and power of key } \\
\text { agents }\end{array}$ & High degree of challenge & Medium & Low \\
\hline $\begin{array}{l}\text { Degree initiators (and/or } \\
\text { possible supporters) of the } \\
\text { innovation have powers to } \\
\text { overcome institutionalized } \\
\text { constraints and/or the } \\
\text { opposition of established } \\
\text { powerful agents and } \\
\text { gatekeepers }\end{array}$ & $\begin{array}{l}\text { High degree of powerlessness } \\
\text { vis-á-vis a powerful } \\
\text { establishment and } \\
\text { institutional constraints such } \\
\text { as monopolistic markets and } \\
\text { stable political domination of } \\
\text { any opposition }\end{array}$ & Medium & $\begin{array}{l}\text { High degree of power } \\
\text { vis-à-vis powerful opposition } \\
\text { and/or substantial constraints } \\
\text { such as monopoly markets } \\
\text { and tight political structures }\end{array}$ \\
\hline
\end{tabular}

change - and have the means to block innovative initiatives or their implementation. In a word, there may be a major gap between those who have power, on the one hand, and those who have creative ideas and innovative project proposals, on the other hand. One of the drivers of agents seeking and utilizing social power is to be able to develop and try to launch their creative projects—or, on the other hand, to be able to block creative initiatives and developments of others. Power is the common denominator.

In sum, our multi-factor model of creativity implies that innovative initiatives may fail because of one or more factors in the matrix of relevant factors.

Indeed, there are arguably more failures than successes in innovative projects [27]; although through repeated efforts, and learning from one's mistakes or the mistakes of others, eventual success may be accomplished, as the cases of Edison and his incandescent light bulb and the Wright brothers and their flying machines illustrate (see Part II). An initiative is likely to be unsuccessful, particularly if it is complex and revolutionary, where (i) the idea of the innovation - its functions, performance or appearance characteristics - is poorly defined; or the idea is misleading or a misfit with natural laws and conditions (e.g., laws of electricity, magnetism, and gravitation) (ii) there are deficiencies in quantities or qualities of inputs whether material resources or deficiencies in the producers and experts (including weakness in motivation and self-confidence) (iv) the entity, its appearance and other features as well as its functioning (and performance including cost properties, reliability, compatibility with other systems) evoke opposition and rejection due to major norms, institutional arrangements, and powerful agents; ${ }^{19}$ (v) there are internal incompatibilities and lack of correspondences among inputs, between production modalities and inputs, or between the outputs and the context; subsystems or subcomponents do not correspond or interface properly with one another.

Thus, because of any one of a number of factors, failures of innovative initiatives are many, whether the innovation agent is an individual, a well-situated network, an informal or formal group, or complex social system such as an entire society. Examples are numerous.

As pointed out earlier, cold fusion (chemically assisted nuclear reactions (CANR)) groups (1989 and later) managed to produce what appeared to

\footnotetext{
19 In some cases of blockage, there may be a major gap between those who have power, on the one hand, and those who have creative ideas and innovative project proposals, on the other hand. One of the motivations of agents utilizing and seeking power is to be able to develop and try to launch their creative projects or, on the other hand, to be able to block creative initiatives and developments of others.
} 
be promising results but they were not verifiable; since then much of the natural science community has considered this innovative initiative as a conceptual and empirical failure. (However, several international research teams continue since the initial efforts to conduct "cold fusion" research, and there are regular conferences and marginal journals publishing relevant articles on the subject).

- Linus Pauling's group failed to identify the correct DNA structure, while Crick and Watson got it right in the same time period.

- Germany failed to develop an atom bomb but had top physicists and engineers, as well as resources (for instance, uranium in former Czechoslovakia), but the model used and the calculations carried out were apparently incorrect (greatly over-estimating the amount of uranium necessary) and concluded that construction of a bomb would not be possible before the expected end of the war. The miscalculation and conclusion became in part a self-fulfilling prophecy [31]. ${ }^{20}$ On the other hand, in the case of the USA, in contrast, authoritative persons including Einstein proposed the bomb could be constructed in the time scale estimated for the war, and there was access to substantial technical knowledge, and plenty of resources mobilized to bring about the eventual and successful Manhattan Project (see Part II).

- The collapse of communism in the Soviet Union (1917-1991): This massive socio-economic and political experiment in modernization-highly original in many ways - collapsed after almost 75 years. There have been many other such "societal experiments" launched (including socialist and fascist experiments in Europe and South America as well as in the Middle East (Ba' ath Parties modeled on Fascist and Communist parties were established in several Middle East Countries, in particular, Iraq and Syria). Most have been defeated in war, elections, or substantial decline

\footnotetext{
${ }^{20}$ No less a scientist than Werner Heisenberg (1901-1976), one of the creators of quantum theory, was involved in these calculations about what was required for an atom bomb, drawing the conclusion that the war would be over before such a bomb could be accomplished. An hypothesis other than "the miscalculation hypothesis" suggests that Heisenberg and others in Germany deliberately misled the Nazi leadership about the immediate infeasibility of the bomb in order to prevent them from obtaining the bomb. Indeed, there were considerable tensions and distrust between the Nazi government and German scientists as well as problems of collaboration among some German research institutes [31].
}

in public support (however, the Socialist Ba'ath Party of Syria still exists headed by the dictator President Bashar al-Assad). ${ }^{21}$

- There have been numerous failed behavioral science theories and programs: Lombroso's phrenology, Nazi racist theory, Le Bon's theory of the crowd, Montesquieu's climate theory of human behavior; and diverse programs to deal with the criminal and the mentally ill (in this latter respect, "creative" initiatives and experimentation continue to go on).

- Alchemists over many centuries failed to achieve many of their major goals such as turning lead into gold. While they believed that it could be done and that they could do it, they failed after many trials over a very extended period of time. Ironically, in their many endeavors, they produced multitudes of innovations although many of these were unintended. ${ }^{22}$

As several cases of failure indicate, agents initiating innovative attempts may have capabilities and skills, essential resources, excellent organization but the idea or design was faulty or public opposition and institutional barriers prevented realization of the innovation in practice.

\footnotetext{
21 There have been also numerous small-scale experiments, monasteries, nunneries, and particularly intriguing the Hippie Commune movement of the 1960s and 1970s in the USA (in large part, disappearing in the 1980s). These communes showed great variation: some were deeply religious, others completely secular. Some became very much involved in drugs, others forbade drugs altogether; some were more or less self-sustaining agricultural units, others produced artifacts and art, while some devoted themselves to producing music and music albums; a few engaged in violent projects - shootings, bombings (one very recognized group was the Weather Underground (1969-1977), a spinoff from the Students for a Democratic Society (SDS)). These diverse groups defined their own goals and functions differently, made up their own rule regimes, and recruitment patterns, and, in general, shaped their particular organizational and cultural forms.

22 Going several thousand years back, alchemy was an early global knowledge development (China, India, and the Mediterranean area). The ostensible goals of alchemy were, among others, the transmutation of common metals into gold (known as chrysopoeia), the creation of a remedy or panacea to cure all diseases and prolong life indefinitely, and the discovery of a universal solvent. While failing to achieve their ostensible goals, Alchemists originated a structure of basic laboratory techniques, theoretical language, terminology, and experimental methods, some residual forms of which are still found in use today. There were many discoveries in the course of their pursuits; they contributed to metalworking, production of ink, dyes, paints, ceramics, distillation, the composition of many types of acids and bases, the making of a solvent with a solution of caustic potash in alcohol etc. It shared with chemistry a material perspective but entailed also a profound mystical and esoteric ethos.
} 


\section{Conclusions}

In our systems framework, creativity has been consistently and systematically viewed as a function of social, cultural, institutional, and material factors rather than exclusively or even largely psychological or biological factors (although the latter should of course be taken into account). Above all, creativity and innovation are universal human activities, essential to adaptation and sustainability in an evolutionary perspective and in everyday life $[11,12]$.

The sociological systems model outlined and applied in the article helps to conceptualize and analyze creative activity in a perspective differing from system approaches found in psychology and management studies (see Part I), in part by systematically stressing and explicating the social dimensions of human creativity, including the socially based facilitators and constrainers of creativity processes, especially agential and social structural factors (see Part I and Part II).

Major features of the sociological systems framework regarding creativity presented in this article have been (to put it in a nutshell): ${ }^{23}$ (1) the sociocultural and material embeddedness of creativity: the multiple contextual factors (material, social, normative, economic, and political) which play a key role in driving, facilitating, and realizing creative initiatives, on the one hand, or constraining or blocking creative processes and developments, on the other hand; (2) the social character and roles of innovative agents and interacting subsystems in the production of novelties and creative developments; (3) the multiple drivers of innovation and creative development - curiosity, need, fun, challenge of solving a problem, the goal of finding better or more optimal solutions, the pursuit of fortune and fame, and much more; (4) social structures (institutional arrangements and cultural formations) in which agents and their interactions are embedded and constrained as well as facilitated - but which their actions and interactions reproduce and restructure, often as part of their creative activity itself (social structure has been conceptualized as rule regimes); (5) the particular powers, resources, and tools and technologies which are accessed, mobilized

\footnotetext{
23 The ASD systems model of creativity and innovation is grounded and articulated in terms of features and mechanisms that are socially formed, developed, and applied. See Fig. 3B in this part (also, see Figs. 2 and 3A in Parts I and II, respectively, indicating key interrelated components and mechanisms of creativity in our general input-output model (Fig. 1 in Part I) . See also other system approaches [2, 17-19, 26, 28, 30, 32, 33].
}

and utilized in creative development and innovation; (6) the interaction bases of innovative initiatives and developments including particular creativity production functions manifested in interactions such as communication, powering, collaboration, competition, and conflict) ("the context of innovation and discovery"); (7) the potentialities of producing novel concepts, technologies, products, designs and proposals, institutional arrangements and cultural forms (including those in which the actors embed themselves); (8) "the context of reception, acceptance or rejection" of novelties and creative developments; in particular key agents (powerbrokers and gatekeepers) and mechanisms involved in verifying, supporting, legitimizing the realization of creations, on the one hand, or their rejection or suppression, on the other hand. (9) retention and institutionalization processes define and establish a creation as "valuable" or useful - at least in the short-run. Over the long-run - as with many instances of technological innovations creative initiatives and developments may run out in the sand; among other reasons, because they are not fully compatible with the laws of nature or with established powerful norms, institutional arrangements, and agents; or they prove destructive of much in the social and/or ecological environment essential to sustainability. (10) Throughout this article, there have been considerations of power and resource control, interest configurations, initiative-taking, oppositional and conformist processes. We have also pointed out the importance of macro-sociological factors in creative developments and innovation such as democratic culture (Part II) and markets and politics (with the state, large and small enterprises, associations and networks playing key roles) (Parts II and III).

The work presented here implies that contexts, agents, rule regimes, and resource conditions of particular fields, which are considered policy prioritized, should be investigated to identify and map out sources of potential facilitation of, as well as constraint on, innovation. Constraints may be counteracted in order to improve creative developments in key policy areas such as treatment of new, dangerous diseases, expanding renewable energy sources, resource conservation, and protection of the environment. ${ }^{24}$ On

\footnotetext{
24 Times of great social instability and uncertainty are often those where there is a special need or challenge to develop innovations and new systems, even revolutionary ones. There is a paradox, however - the gap between the challenges, on the one hand, and the reluctance of many key actors with resources to face the challenge in creative, new ways - which characterizes in part on temporary conditions. The paradox is explained by the genuine uncertainty in
} 
the other hand, creativity might with justification be constrained policy-wise and institutionally in fields where new developments are dangerously risky and should be restricted or banned, e.g., development of new weapons of mass destruction, hazardous new chemicals and biomedical innovations, experimentation with new kinds of biological materials or human cloning (as well as numerous other potentially harmful developments).

\section{Acknowledgments}

Earlier related collaboration with Svein Andersen, Tom Baumgartner, Marcus Carson, Philippe DeVille, Jerry Ellig, Peter Hall, Ilan Kelman, Atle Midttun, and Alison Woodward has also played a significant role in the development of the sociology of creativity.

\section{References}

[1] S. Andersen and T.R. Burns, Societal Decision-making: Democratic Challenges to State Technocracy. Aldershot, Hampshire: Dartmouth Publications; 1992.

[2] S. Arieti, Creativity: The Magic Synthesis. New York: Basic Books; 1976.

[3] W.B. Arthur, The Nature of Technology. New York: Free Press; 2009.

[4] T. Baumgartner and T.R. Burns, Transitions to Alternative Energy Systems: Entrepreneurs, Strategies, and Social Change. Colorado: Westview Press; 1984.

[5] T. Baumgartner, T.R. Burns, and P. DeVille, The Shaping of Socio-economic Systems: The Application of the Theory of Actor-System Dynamics to Conflict, Social Power, and Institutional Innovation in Economic Life. London and New York: Routledge, 2014.

[6] W.G. Bennis and P. Ward Biederman, Organizing Genius: The Secrets of Creative Collaboration. Basic Books, 1997.

[7] W. Buckley, Sociology and modern systems theory. Oxford, England: Prentice-Hall1, 1967.

the situation, and the unwillingness of many powerful actors to take risks - above all, the possible loss of their power and status-at the same time that risk-taking is absolutely essential to innovation and new developments. One waits suspended between the old, which has lost the assuredness and wide-spread support enjoyed earlier, and the new, which is still unknown and, therefore, cannot command widespread support, in particular financial and political support. A certain inertia pervades our institutions (although, as discussed in Part II, the Sustainability Revolutions suggests many exceptions). The question today is: Can human societies - and their governments and entrepreneurial groups ready and willing to try to meet the challenge - find effective ways and means to stimulate creative development and innovation and overcome risk-aversion and other barriers to establishing rapidly enough a sustainable economy and society?
[8] T. Burns, System Theories In: The Encyclopedia of Sociology, Blackwell Publishing, Malden, Mass, 2006.

[9] T.R. Burns, Baumgartner T, DeVille P, 1985. Man, Decisions, and Society. London: Gordon and Breach.

[10] T.R. Burns, U. Corte and N. Machado, Toward a Universal Theory of the Human Group: Sociological Systems Framework Applied to the Comparative Analysis of Groups and Organizations.” ULI/CIES Report No. 191/2014. Lisbon: University of Lisbon Institute/CIES, 2014.

[11] T.R. Burns and T. Dietz, Revolution: An Evolutionary Perspective. International Sociology 16(4) (2001), 531-555.

[12] Burns TR, Dietz T, Cultural Evolution: Social Rule Systems, Selection, and Human Agency. International Sociology 7 (1992), 259-283.

[13] T.R. Burns, and P. Hall, editors. The Meta-Power Paradigm Impacts and Transformations of Agents, Institutions, and Social Systems Capitalism, State, and Democracy in a Global Context. Peter-Lang publishing, 2012.

[14] R. Carson, The Silent Spring. Houghton Mifflin: Boston, Mass; 1962.

[15] M. Carson, T.R. Burns and D. Gomez Calvo, Public Policy Paradgims: Theory and Practice of Paradigm Shifts in the European Union. Peter Lang, Frankfurt/New York/Oxford, 2009.

[16] G. Cattani, S. Ferriani and M. Colucci, Creativity, Legitimacy, and Social Structure: A Core-Periphery Perspective. In: Jones C, Lazersen M, and Sapsed, J. The Oxford Handbook of the Creative Industries. Oxford: Oxford University Press; 2015

[17] M. Csikszentmihalyi, "Society, culture, and person: Creativity.” In: R.J. Sternberg (ed.). Cambridge: Cambridge University Press; 1990.

[18] M. Csikszentmihalyi, Society, culture, and person. A system view of creativity. In R.J. Sternberg The nature of creativity. (pp.325-339). New York: Cambridge University Press; 1988.

[19] E. Gorny, editor. Dictionary of Creativity: Terms, Concepts, Theories \& Findings in Creativity Research. Netslova, Russia. http://creativity.netslova.ru/Meme.html. 2007.

[20] M. Granovetter, Economic Action and Social Structure: The Problem of Embeddedness, American Journal of Sociology 91, (1985), 481-510.

[21] P. Israel, Edison: A Life of Invention. New York: John Wiley \& Sons.

[22] M. Lönnroth, P. Steen and T.B. Johansson, Energy in Transition. Stockholm: Secretariat for Future Studies. Published in 1980 by University of California Press; 1977.

[23] M. Lönnroth, T.B. Johansson and P. Steen, Solar versus Nuclear. New York: Pergamon, 1980.

[24] M. Lonnroth, The Oil Peak and Beyond. Stockholm: Beijer Institute and Secretariat for Future Studies; 1978a.

[25] M. Lönnroth, Energy Futures for Sweden.” Stock-holm: Secretariat for Future Studies; 1978b.

[26] D.W. MacKinnon, Creativity: A Multi-faceted Phenomenon. In Roslanksy J, editor. Creativity. Amsterdam: North-Holland Publishing; 1970.

[27] N. MacLaughlin, Collaborative Circles and Their Discontents. Sociologia (2) (2008), 1-36.

[28] R.L. Mooney and T.A. Razik, editors. Explorations in Creativity, New York: Harper and Row; 1967. 
[29] R.R. Nelson and R. Langlois, Industrial innovation policy: Lessons from American history. Science 219(4586), 814-8.

[30] G.J. Puccio and J.F. Cabra, Organizational creativity: A systems perspective. In Kaufmann J, \& R.J. Sternberg editors. The Cambridge Handbook of Creativity (pp. 145-173). New York: Cambridge University Press; 2010.

[31] P.L. Rose, Heisenberg and the Nazi Atom Bomb Project 1939-1945. Berkeley: University of California Press.

[32] R.K. Sawyer, Explaining Creativity: The Science of Human Innovation, Oxford University Press; 2012.

[33] R.K. Sawyer Group Genius: The Creative Power of Collaboration, Basic Books; 2008.
[34] A. Swidler, Culture in Action: Symbols and Strategies. American Sociological Review 51(2)(1986), 273.

[35] B. Wittrock and J. Lindstrom, Implementation beyond Hierarchy: Swedish Energy Research Policy. European Journal of Political Research 10 (1982), 131-143.

[36] A.E. Woodward, J. Ellig and T.R. Burns, Municipal Entrepreneurship and Energy Policy: A Five Nation Study of Politics, Innovation, and Social Change. New York: Gordon and Breach; 1994.

[37] M. Zeleny, "Technology and High Technology: Support Net and Barriers to Innovation," Advanced Management Systems 1(1) (2009), 8-21. 